\title{
PERFORMANCE ASSESSMENT OF CROSSES BETWEEN GADAM AND HARDCORE TANNIN SORGHUM IN HYBRID LINES PRODUCTION
}

\author{
Cecilia A. Shinda ${ }^{1}$, Josiah N. Gitari ${ }^{1}$, Paul N. Nthakanio ${ }^{1 *}$, Steven Runo ${ }^{2}$, \\ Bernard Gichimu ${ }^{1}$, Samuel Maina ${ }^{3}$
}

${ }^{1}$ Department of Agricultural Resource Management, University of Embu, Kenya

${ }^{2}$ Department of Biochemistry, Microbiology, and Biotechnology, Kenyatta University, Nairobi, Kenya

${ }^{3}$ Department of Biological Sciences, University of Embu, Kenya

Received - June 10, 2021; Revision - August 11, 2021; Accepted - August 28, 2021

Available Online-August 30, 2021

DOI: http://dx.doi.org/10.18006/2021.9(4).417.431

KEYWORDS
Compatibility
F $_{1}$ hybrid lines
Gadam sorghum
Heterosis
Maternal influence

\begin{abstract}
Gadam cultivar of sorghum has been characterized by low yields compared to the international yield levels of sorghum. In this research, Gadam was crossed with Serena, Seredo, and Kari/Mtama-1 in an attempt to increase yield through heterosis. The objective of this study was to determine the level of compatibility and heterosis in crosses between Gadam and the three sorghum lines in a reciprocal crossing. Gadam was crossed with the three lines and their reciprocals to make six treatments that were subjected to compatibility and heterosis tests. The $\mathrm{F}_{1}$ hybrid lines and their parental controls were sown in a randomized complete block design in three replicates. Compatibility and heterosis data variances were analyzed using $\mathrm{R}$ statistical software. The cross between Gadam x Serena, Serena x Gadam and the parent Gadam exhibited moderate mean plant height ranging from $99.5 \mathrm{~cm}$ to $120.5 \mathrm{~cm}$. The cross Gadam x Serena recorded a desirable negative mid-parent heterosis of -19.89 and -16.16 for plant height and days to maturity respectively. All $F_{1}$ hybrids recorded positive mid-parent heterosis for the panicle length, the number of reproductive tillers, a thousand seed weight, and the number of tillers per plant. The crosses Gadam $x$ Seredo, Seredo x Gadam, Gadam x Serena and Kari/Mtama-1 x Gadam recorded significantly lower grain filling percentages compared to their parents. In conclusion, the $F_{1}$ hybrids differed significantly from their reciprocal crosses especially in days of heading, flowering, and maturity indicating a significant maternal influence in these traits. Also, the mid-parent and better parent heterosis had a nonsignificant difference in quantitative traits assessed except for the plant height and grain filling percentage.
\end{abstract}

* Corresponding author

E-mail: nthakanio.paul@embuni.ac.ke (Paul N. Nthakanio)

Peer review under responsibility of Journal of Experimental Biology and Agricultural Sciences.

Production and Hosting by Horizon Publisher India [HPI] (http://www.horizonpublisherindia.in/).

All rights reserved.
All the articles published by Journal of Experimental Biology and Agricultural Sciences are licensed under a Creative Commons Attribution-NonCommercial 4.0 International License Based on a work at www.jebas.org.

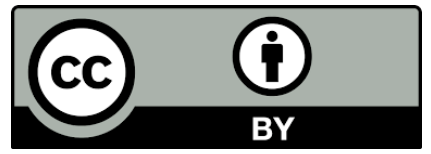




\section{Introduction}

Sorghum (Sorghum bicolor (L.) Moench) is a Gramineae cereal crop (Mofokeng \& Shargie, 2016) that is important due to its drought tolerance (Amelework et al., 2016). It is ranked fifth globally in importance following rice, maize, wheat, and barley (FAOSTAT, 2017). A wide range of products are made from it in form of food for humans and feed for animals (Aruna \& Visarada, 2019). These include cakes, beer, and animal dairy meals (Wu et al., 2016). Other by-products include fuel and building materials also made from sorghum (Prażak, 2016). In Sub-Saharan Africa, sorghum is ranked second after maize (Hadebe et al., 2017). Major sorghum growing countries in Africa includes Nigeria, Sudan, and Tanzania (Abraha et al., 2017; Aruna \& Visarada, 2019).

In Kenya, the major sorghum growing regions include Western, Nyanza, Northern Rift valley, Coast, and Central regions (Ngugi \& Maswili, 2011). In the period 2015-2019, the area under sorghum production and the total yields were 225,177 hectares and 185,400 tons respectively (FAOSTAT, 2019). The average yield within the period was 0.81 tons per hectare. This is low despite the development of new improved varieties in the country (Muui et al., 2013). Kenya produces only $0.8 \%$ of the total production of sorghum in Africa however, the crop has the potential to enhance household food security especially in marginal regions (Ochieng et al., 2011).

Gadam sorghum is widely cultivated in semi-arid regions of lower and upper eastern Kenya (Mwadalu \& Mwangi, 2013). It is a dwarf variety that tolerates low rainfall of about $200 \mathrm{~mm}$ and matures in two and a half to three months (Esipisu, 2011). This variety of sorghum is commercially produced mainly for brewing because of its good malting quality and this has offered higher returns to farmers (Kavoi et al., 2013). However, the challenge is that the yield of Gadam sorghum has remained low over the years compared to international levels ( De Mey et al., 2012; Mutisya et al., 2016).

Hybrids have recorded higher yields compared to pure lines (Xie et al., 2019). This is possible by crossing compatible cultivars that display hybrid vigour at $\mathrm{F}_{1}$. Compatibility is the highest degree of fitness between the male and female gametes that results in fertilization in the flowering plants (Hettyey et al., 2010). Breeding among compatible crop species has led to the production of both forage and grain sorghum varieties (Bean et al., 2013; Grossenbacher et al., 2017). Compatibility among Eu-sorghum species has enhanced sorghum breeding (Ohadi et al., 2017) leading to the selection of desirable traits such as resistance to diseases, insect, and herbicide. It has also led to increased protein digestibility, water use efficiency, improved nitrogen uptake and utilization, and salt tolerance (Maheswari et al., 2010; Akosambo et al., 2011; Kumar et al., 2012; Che et al., 2016; Massel et al.,
2016). Sorghum bicolors sp arundinaceum is an important germplasm source for traits such as increased grain size, photoperiod insensitivity, less seed shattering, post and preanthesis drought tolerance, and dwarfness (Jordan et al., 2011). These traits have led to improved yields in sorghum hybrids. The compatibility of sorghum with its wild relatives including sudangrass, shatter cane, and Johnson grass has been reported too, which widens the scope of breeding (Wang et al., 2016). In some instances genetic barriers such as pollen-pistil incompatibility limit breeding (Ohadi et al., 2017). To induce viable seeds, there must be compatibility between the pollen grain and the stigma of the recipient parent. This enables germination and development of a pollen tube to successfully transfer the sperm to the ovary for fertilization of the central cell together with the ovule (Wright et al., 2013). If the pollen is non-compatible, the pistil will reject the pollen tube leading to non-fertilization of the ovule (Leducq et al., 2010; Young et al., 2012). Inhibitory gene, Iap that leads to pollenpistil incompatibility has been reported in both maize and sorghum (Visarada \& Venkateswaran, 2018). However, the presence of the iap gene in its recessive form has increased the likelihood of interspecific hybridization in sorghum lines (Wang et al., 2016). This has facilitated the quick transfer of desirable genes in sorghum breeding programs

Hybrid technology has increased sorghum yield per acre to over 50\% and 47\% in China and India respectively (Madić et al., 2014; Ashok et al., 2019). Sorghum breeders have focused mainly on breeding for cold-tolerant, reduced maturity period, high food quality, salt tolerance, and insect resistance (Burrow et al., 2011; Calone et al., 2020). Although new sorghum varieties have been released in Kenya, their yield is still low compared to international levels (Timu et al., 2014).

The exploitation of heterosis in $F_{1}$ hybrids has been used to improve sorghum yield (Smale et al., 2018). Heterosis is the ability of $F_{1}$ hybrids to perform better compared to their respective parents (Aruna \& Cheruku, 2019). However, heterosis is limited by incompatibility in the parents which brings about sterility in $F_{1}$ hybrids. This is prevented by the introgression of the wide compatibility gene into the parents. In sorghum, heterosis is expressed in form of early anthesis, earlier maturity, increased height, larger panicle length, and high panicle weight in the hybrids (Crozier et al., 2020). Hybrid sorghum lines have been used to increase yields especially in West African areas (Kante et al., 2019). Smale et al. (2018) reported a yield advantage of up to $17-47 \%$ in hybrids compared to purebred lines. However, in Kenya sorghum hybrid seeds have not been developed because the farmers are too poor to afford them (Rattunde et al., 2013).

The East African Breweries Limited (EABL) has contracted farmers to produce Gadam sorghum for use in brewing (Kavoi et al., 2013). In the year 2010, the demand for Gadam by the EABL 
was estimated to be 60,000 metric tons but farmers gained only 2,000 metric tons which were below its demand (Mwadalu \& Mwangi, 2013). To realize the full potential of Gadam, there is a need to increase its yield. Therefore, this study is aimed at evaluating the performance of hybrid lines developed by crossing Gadam and the three main landrace sorghum varieties grown in Kenya for improved performance.

\section{Materials and Methods}

\subsection{Study site description}

The study was conducted at the University of Embu research farm between November 2019 and September 2020 which lies at $0^{\circ} 35^{\prime} 25^{\prime \prime} \mathrm{S}$ and $37^{\circ} 25^{\prime} 31^{\prime \prime} \mathrm{E}$. This area is located at $1463 \mathrm{~m}$ above sea level, which is between the upper midland 2 (UM2) and UM3 Agro-ecological zones in the South-eastern slopes of the Mount Kenya region. It has a bimodal rainfall pattern and receives an average rainfall amount of $1230 \mathrm{~mm}$ annually. The short rains occur between October and December while the long rains are experienced between March and June (Micheni et al., 2018). The mean annual temperature experienced in the area is $19.6^{\circ} \mathrm{C}$. The annual maximum and minimum mean temperatures are $25^{\circ} \mathrm{C}$ and $14.1^{\circ} \mathrm{C}$ respectively. The soils found in the area are volcanic and Humic Nitisols (Munyao et al., 2019), with deep, well-aerated, and have a clay texture that is friable with average to high inherent fertility (Micheni et al., 2018).

\subsection{Sorghum seed materials}

Elite sorghum varieties Gadam, Kari/Mtama-1 (Ck), Serena, and Seredo were obtained from the Kenya Agricultural and Livestock Research Organization (KALRO) Seed Unit at Katumani. The reciprocal crossing was done among the varieties to obtain $F_{1}$ hybrid lines (Kim et al., 2016; Seo et al., 2019) which were used as the main materials in this research. The main variety in the crossing was Gadam sorghum. It was crossed with Kari/Mtama-1, Serena, and Seredo and also reciprocal of each line.

\subsection{Synchronization of the heading time}

Sorghum varieties Gadam, Kari/Mtama-1, Serena, and Seredo heads at 45, 58, 71, and 70 days respectively (Mwadalu \& Mwangi, 2013). Due to this difference in the heading time, the sowing of the varieties was staggered over three weeks. This was to ensure that when Gadam sorghum heads, there was an accompanying pollen donor flowering at the same time.

\subsection{Development of $F_{1}$ hybrid seeds}

At the stage of the emergence of the panicle from the flag leaf, Gadam sorghum was used in the reciprocal crossing with each of the three selected varieties (Serena, Seredo, and Kari/Mtama-1) to get $F_{1}$ seeds. The main crosses were Gadam x Serena, Gadam x Seredo and Gadam x Kari/Mtama-1 while reciprocal crosses were Serena x Gadam, Seredo x Gadam and Kari/Mtama-1 x Gadam. The reciprocal cross was done to test the presence of cytoplasmic effects (Maluk et al., 2019). Manual emasculation and artificial pollination were carried out as per the method given by Kim et al. (2016) and Seo et al. (2019). First, ten plants at the stage of panicle emergence from flag leaf of each variety were tagged. Five plants out of the ten were sampled to be male pollen donors while the other five plants were used as pollen recipients or female parents in each of the varieties in the cross. A third of the glume of the female chosen flowers was cut from the top tip with a pair of scissors to open it. This was followed by careful removal of the anthers using a pair of fine-tip forceps after which crosspollination was done by dusting fertile pollen to emasculated panicle.

\subsection{Experimental design and layout}

Plant materials were the six hybrid lines developed in section 2.4. The parents together with their $F_{1}$ hybrids were sown in a Randomized Complete Block Design (RCBD). The experiment had ten treatments that were evaluated in three replicates. These included the six crosses and their parental controls. Each treatment was assigned an experimental plot, measuring $0.75 \mathrm{~m}$ by $2.0 \mathrm{~m}$ with $0.5 \mathrm{~m}$ alleys between the plots and between the blocks. Sowing ground was pulverized using a hoe to achieve a moderately smooth seedbed with a fine tilth. Seed drilling was done in rows at a spacing of $75 \mathrm{~cm}$ between the rows and later thinned to $20 \mathrm{~cm}$ between plants (Adams et al., 2015). After planting, standard crop husbandry practices were done according to Hanway \& Olson, (2012), Thivierge et al., (2015), and Bonin et al. (2016). Five plants in each treatment were selected and tagged before flowering for evaluation of compatibility and heterosis.

\subsection{Data collection}

For each treatment in all replicates, five (5) plants were identified and tagged for data collection. Parameters evaluated included the number of tillers per plant, grain filling percentage, rate of germination, days to flowering, days to heading, days to maturity, number of reproductive tillers per plant, plant height $(\mathrm{cm})$, the weight of 1000 seeds, panicle length, panicle compactness, and tannin content.

\subsection{Compatibility determination and other traits evaluation}

To determine compatibility, the panicles of the five tagged plants in each treatment were cut at maturity then the total number of filled glumes were counted against the total number of glumes. Then, the compatibility (in form of grain filling percentage) was calculated using the formula described by Chen et al. (2019): 
Percent grain filling $(\%)=($ Total number of filled glumes $\div$ Total number of glumes) $\mathrm{x} 100$

Other compatible traits were evaluated using sorghum descriptors (Mohammed et al., 2015; Suguna et al., 2021). Germination rate was calculated in percentage $(\%)$ as;

Percent seed germination $=($ Number of seeds that germinated per each petri dish $\div$ total number of seeds that were placed in each petri-dish) x 100

Plant height was measured in centimeters using a measuring tape as the length between the soil surface to the tip of the panicle. Days to heading were determined as the days from germination to $50 \%$ panicle initiation. Days to flowering were taken as the total number of days from sowing to when each tagged plant reached the half bloom phase. Panicle length was measured in centimeters as the length from the panicle's base to the top while the weight of a thousand seeds was determined by weighing a thousand seeds in each treatment at $12 \%$ moisture content. The number of reproductive tillers was determined by counting the individual tillers that produced reproductive heads in each treatment. Days to maturity were taken as the total number of days from sowing to when the seeds of each tagged plant reached the physiological maturity stage. This was indicated by turning black of layer on the base of the kernel. Panicle compactness was also determined at the physiological stage on 15 plants sampled from each treatment in each replicate using a scale of 1 to 3 where $1=$ loose panicle, $2=$ semi-loose panicle, and 3 = compact panicle (Sulistyawati et al., 2019). Data on tannin content was collected in triplicate and the results were expressed as the average result of the value in milligram per gram $(\mathrm{mg} / \mathrm{g})$.

\subsection{Tannin content determination}

Whole mature grains from each of the treatments (section 2.5) were used for the estimation of tannin content. The grains were harvested manually, hand-threshed, winnowed, and ground into fine flour using a high-speed universal disintegrator (FW80-I). It was then sieved using a 0.5 -mesh screen to separate the flour and husks. The flour was then kept at $4^{\circ} \mathrm{C}$ in polythene bags until use. Modified vanillin- $\mathrm{HCl}$ assay method was used to determine tannin content using a digital spectrophotometer (ME 801) (Dykes, 2019).

\subsection{Estimates of heterosis}

The better parent (BP) heterosis and mid parent (MP) heterosis were estimated as per the method described by Suguna et al. (2021):

Better parent heterosis $(\%)=\left[\left(\mathrm{F}_{1}-\mathrm{BP}\right) / \mathrm{BP}\right] \mathrm{x} 100$

Mid parent heterosis $(\%)=\left[\left(\mathrm{F}_{1}-\mathrm{MP}\right) / \mathrm{MP}\right] \times 100$
Where, $F_{1}=$ mean value of $F_{1}$ hybrid, $B P=$ mean value of the better parent in the cross, MP = average mean value of the two parents in the cross, $\%=$ percentage, and $\mathrm{x}=$ cross multiplication sign.

\subsection{Data analysis}

The tannin content and quantitative data collected were subjected to a one-way analysis of variance (ANOVA) using $\mathrm{R}$ statistical software (R Development Core Team, 2015). The qualitative data on panicle compactness was first transformed using the $\log _{10}(\mathrm{x}+$ 1) before subjecting the data to ANOVA. Mean separation was done using Tukey's Studentized Range (HSD) at a 95\% confidence level using package agricolae in $\mathrm{R}$ as described by De Mendibru (2019). The degree of relationship between the quantitative characters was assessed using the Pearson correlation coefficient (r) in the R package ggpubr (Kassambara, 2018). A t-test analysis was carried out using XLSTAT version 2020 to test whether heterosis was significantly different than zero. The difference between the means was determined at a $95 \%$ confidence interval.

\section{Results}

\subsection{Performance of sorghum $F_{1}$ hybrids and their parents for phenotypic traits}

The cross between Gadam and Serena recorded the lowest mean plant height among hybrids in the growth period (Table 1). However, it was not significantly different from its reciprocal cross (Serena x Gadam) apart from in weeks 2 and 4, when it recorded $30.71 \mathrm{~cm}$ and $58.40 \mathrm{~cm}$ respectively while its reciprocal cross recorded mean plant height of $45.77 \mathrm{~cm}$ and $81.31 \mathrm{~cm}$ respectively (Table 1). In weeks 5 and 6, Gadam x Serena recorded significantly lower mean plant height than all other crosses apart from its reciprocal cross. Also, it was significantly lower than parental lines in the study apart from Gadam (Table 1). The cross Kari/Mtama-1 x Gadam recorded the highest plant height with a mean of $159.47 \mathrm{~cm}$ with no significant difference from Gadam $\mathrm{x}$ Kari/Mtama-1 (142.29 cm) at week 6 (Table 1). The cross also had the highest mean plant height among the $\mathrm{F}_{1}$ hybrids from week 3-6, but it had a significant difference with the Gadam parent. There were no significant variations observed in the rate of germination among the crosses and their reciprocals (Table 2). In terms of panicle length, significant variations $(p<0.01)$ were observed among the crosses, reciprocals, and their parents. Kari/Mtama-1 $\mathrm{x}$ Gadam recorded the highest panicle length of $23.78 \mathrm{~cm}$ which was significantly different from its Gadam parent $(20.20 \mathrm{~cm})$ but not the Kari/Mtama-1 parent. Among the crosses, the panicle length of Kari/Mtama-1 X Gadam was only significantly higher than Serena x Gadam that had $20.67 \mathrm{~cm}$. It was also, significantly higher than Serena that had $19.73 \mathrm{~cm}$ (Table 2). All the crosses had significant variations $(\mathrm{p}<0.001)$ with their reciprocals in days to flowering 
and days to heading (Table 2). The cross Gadam x Kari/Mtama-1 (with 43.80 days) recorded significantly low days to heading than all other $F_{1}$ hybrids. Gadam x Kari/Mtama-1 with 52.20 days was the earliest to flower and was significantly lower than its parents and its reciprocal cross. In terms of days to maturity, the cross Gadam x Serena recorded significantly lower days to maturity (87.00 days) than its reciprocal (Serena $x$ Gadam) that had 103.27 days. Gadam x Kari/Mtama-1 (93.60 days) had no significant difference with its reciprocal cross Kari/Mtama-1 x Gadam (97.93 days). Crosses Gadam x Serena and Gadam x Seredo recorded significantly lower days to maturity than their reciprocal crosses (Table 2). Also, the crosses had significant differences with their reciprocals in grain filling percentage, while in the case of number of tillers per plant, number of reproductive tillers, and weight of 1000 seeds in all the crosses did not significantly $(\mathrm{p}>0.05)$ differ (Table 2).

Panicle compactness among the crosses and their reciprocals is shown in Table 3. A significant difference $(p<0.001)$ was observed among the crosses and their reciprocals apart from Gadam x Serena and its reciprocal that both recorded a mean of 2.77 for compact panicle. Among the parents, the highest mean recorded for semi-loose and loose panicle was 2.77 for Seredo and Kari/Mtama-1 respectively. Also, the parents Gadam and Serena recorded the highest mean of 2.77 for compact panicle. The cross Gadam x Seredo exhibited a mean panicle compactness values of 1.84 for compact and 2.37 for semi-loose panicle. Its reciprocal cross exhibited a mean panicle compactness values of 2.37 for compact and 1.84 for semi-loose panicle. The cross Gadam $\mathrm{x}$
Kari/Mtama-1 had a mean panicle compactness values of 1.78 for compact and 2.39 for loose while its reciprocal cross had 2.48 for compact and 1.59 for loose panicle (Table 3).

\subsection{Pearson correlations between quantitative traits}

Both positive and negative significant $(\mathrm{p}<0.05)$ correlations were observed between the quantitative variables that included grain filling percentage, the weight of a thousand seeds, days to heading, days to flowering, days to maturity, number of tillers per plant, number of reproductive tillers, plant height and panicle length (Table 4). A positive correlation was observed both in days to heading and days to maturity $(r=0.814, p<0.004)$ and in days to heading and days to flowering $(r=0.990, p<0.001)$. However, days to heading correlated negatively to a thousand seed weight $(\mathrm{r}$ $=-0.757, \mathrm{p}<0.011)$ while days to maturity correlated positively with days to flowering $(\mathrm{r}=0.770, \mathrm{p}<0.009)$. Both days to flowering and days to maturity were found to correlate negatively with a thousand seed weight at $\mathrm{r}=-0.724, \mathrm{p}<0.018$ and $\mathrm{r}=-$ $0.858, \mathrm{p}<0.001$ respectively. The number of tillers per plant correlated positively with the number of reproductive tillers $(\mathrm{r}=$ $0.980, p<0.001)$. Grain filling percentage was found to correlate negatively with panicle length and weight of a thousand seeds at $\mathrm{r}$ $=-0.701, \mathrm{p}<0.024$ and $\mathrm{r}=-0.682, \mathrm{p}<0.030$ respectively. $\mathrm{A}$ significant positive correlation was observed between a thousand seed weight and panicle length $(r=0.678, \mathrm{p}<0.031)$ while plant height correlated negatively with both number of reproductive tillers $(r=-0.832, p<0.003)$ and number of tillers per plant $(r=-$ $0.793, \mathrm{p}<0.006)$.

Table 1 Analysis of variance showing means of plant height variable for the six weeks

\begin{tabular}{|c|c|c|c|c|c|c|}
\hline Treatments & $\begin{array}{c}\text { PH (WK1) } \\
(\text { Mean } \pm \text { S.E) }\end{array}$ & $\begin{array}{c}\text { PH(WK2) } \\
(\text { Mean } \pm \text { S.E) }\end{array}$ & $\begin{array}{c}\text { PH (WK3) } \\
(\text { Mean } \pm \text { S.E) }\end{array}$ & $\begin{array}{c}\text { PH(WK4) } \\
(\text { Mean } \pm \text { S.E) }\end{array}$ & $\begin{array}{c}\text { PH (WK5) } \\
(\text { Mean } \pm \text { S.E) }\end{array}$ & $\begin{array}{c}\text { PH (WK6) } \\
(\text { Mean } \pm \text { S.E) }\end{array}$ \\
\hline Gadam & $19.347^{c} \pm 3.84$ & $29.327^{\mathrm{d}} \pm 3.87$ & $46.360^{\mathrm{d}} \pm 5.50$ & $63.880^{\mathrm{de}} \pm 2.93$ & $85.633^{\text {ef }} \pm 7.62$ & $103.287^{\mathrm{f}} \pm 4.18$ \\
\hline Serena & $32.420^{\mathrm{a}} \pm 2.47$ & $47.893^{\mathrm{ab}} \pm 6.05$ & $79.445^{\mathrm{ab}} \pm 1.73$ & $106.260^{\mathrm{ab}} \pm 3.97$ & $125.933^{\mathrm{bcd}} \pm 2.65$ & $144.747^{\mathrm{bcd}} \pm 2.18$ \\
\hline Seredo & $24.801^{\mathrm{abc}} \pm 4.58$ & $33.720^{\text {bcd }} \pm 6.46$ & $81.493^{\mathrm{ab}} \pm 3.95$ & $110.753^{\mathrm{ab}} \pm 3.73$ & $135.260^{\mathrm{abc}} \pm 2.60$ & $151.007^{\mathrm{abc}} \pm 0.90$ \\
\hline Kari/Mtama-1 & $31.187^{\mathrm{a}} \pm 1.52$ & $48.927^{\mathrm{a}} \pm 3.81$ & $94.053^{\mathrm{a}} \pm 3.18$ & $126.187^{\mathrm{a}} \pm 3.03$ & $155.693^{a} \pm 5.03$ & $170.347^{\mathrm{a}} \pm 2.86$ \\
\hline $\begin{array}{c}\text { Gadam x } \\
\text { Serena }\end{array}$ & $23.860^{\mathrm{abc}} \pm 1.61$ & $30.713^{\mathrm{cd}} \pm 3.23$ & $43.533^{\mathrm{d}} \pm 4.54$ & $58.401^{\mathrm{e}} \pm 3.25$ & $79.100^{\mathrm{f}} \pm 6.45$ & $99.480^{\mathrm{f}} \pm 2.21$ \\
\hline $\begin{array}{l}\text { Gadam x } \\
\text { Seredo }\end{array}$ & $20.133^{\mathrm{c}} \pm 3.85$ & $35.160^{\mathrm{abcd}} \pm 4.39$ & $63.893^{\mathrm{bcd}} \pm 6.87$ & $97.067^{\mathrm{bc}} \pm 5.88$ & $110.253^{\text {cde }} \pm 5.21$ & $127.127^{\mathrm{de}} \pm 6.48$ \\
\hline $\begin{array}{c}\text { Gadam x } \\
\text { Kari/Mtama-1 }\end{array}$ & $27.827^{\mathrm{abc}} \pm 3.67$ & $44.533^{\mathrm{abc}} \pm 5.72$ & $76.067^{\mathrm{abc}} \pm 3.85$ & $106.987^{\mathrm{ab}} \pm 3.59$ & $124.340^{\mathrm{bcd}} \pm 2.63$ & $142.293^{\text {bcde }} \pm 2.78$ \\
\hline $\begin{array}{c}\text { Serena } x \\
\text { Gadam }\end{array}$ & $29.287^{\mathrm{ab}} \pm 1.91$ & $45.773^{\mathrm{ab}} \pm 2.64$ & $56.563^{\mathrm{cd}} \pm 5.99$ & $81.313^{\mathrm{cd}} \pm 5.30$ & $102.440^{\mathrm{def}} \pm 9.02$ & $120.473^{\mathrm{ef}} \pm 7.10$ \\
\hline $\begin{array}{c}\text { Seredo x } \\
\text { Gadam }\end{array}$ & $19.080^{\mathrm{c}} \pm 1.30$ & $29.680^{d} \pm 1.13$ & $71.420^{\mathrm{abc}} \pm 4.07$ & $99.780^{\mathrm{bc}} \pm 5.54$ & $117.873^{\mathrm{bcd}} \pm 3.99$ & $136.013^{\text {cde }} \pm 6.61$ \\
\hline $\begin{array}{l}\text { Kari/Mtama-1 } \\
\text { x Gadam }\end{array}$ & $22.227^{\mathrm{bc}} \pm 3.11$ & $38.920^{\text {abcd }} \pm 8.40$ & $84.293^{\mathrm{ab}} \pm 3.85$ & $114.467^{\mathrm{ab}} \pm 4.54$ & $143.127^{\mathrm{ab}} \pm 5.59$ & $159.473^{\mathrm{ab}} \pm 5.59$ \\
\hline $\mathrm{P}-$ Value & $0.031^{*}$ & $0.048^{*}$ & $<0.001^{* * *}$ & $<0.001^{* * *}$ & $<0.001^{* * *}$ & $<0.001^{* * *}$ \\
\hline
\end{tabular}

Means with the same letter within the column are not significantly different; ${ }^{*}{ }^{* * *}$ significant at $5 \%$ and $0.1 \%$ respectively. S.E: standard error; PH: plant height; WK: week

Journal of Experimental Biology and Agricultural Sciences

http://www.jebas.org 
Table 2 Analysis of variance showing means of quantitative growth and yield variables

\begin{tabular}{|c|c|c|c|c|c|c|c|c|c|}
\hline Treatment & $\begin{array}{c}\mathrm{RG}(\%) \\
(\text { Mean } \pm \text { S.E) }\end{array}$ & $\begin{array}{c}\text { DTH } \\
(\text { Mean } \pm \text { S.E) }\end{array}$ & $\begin{array}{c}\text { DTF } \\
(\text { Mean } \pm \text { S.E })\end{array}$ & $\begin{array}{c}\text { DTM } \\
(\text { Mean } \pm \text { S.E })\end{array}$ & $\begin{array}{c}\text { NTPP } \\
(\text { Mean } \pm \text { S.E) }\end{array}$ & $\begin{array}{c}\text { NRT } \\
(\text { Mean } \pm \text { S.E) }\end{array}$ & $\begin{array}{c}\text { PL } \\
(\text { Mean } \pm \text { S.E })\end{array}$ & $\begin{array}{c}\% \text { GF } \\
(\text { Mean } \pm \text { S.E })\end{array}$ & $\begin{array}{c}\text { W1000S } \\
(\text { Mean } \pm \text { S.E })\end{array}$ \\
\hline Gadam & $70.000^{\mathrm{ab}} \pm 2.89$ & $55.733^{\mathrm{de}} \pm 0.37$ & $65.267^{\mathrm{ef}} \pm 0.27$ & $97.667^{\mathrm{de}} \pm 0.27$ & $1.533^{\mathrm{ab}} \pm 0.27$ & $1.333^{\mathrm{a}} \pm 0.18$ & $20.200^{\mathrm{b}} \pm 0.85$ & $98.519^{a} \pm 0.10$ & $34.573^{\mathrm{a}} \pm 4.10$ \\
\hline Serena & $60.000^{\mathrm{ab}} \pm 2.89$ & $65.067^{\mathrm{ab}} \pm 0.52$ & $74.533^{\mathrm{a}} \pm 0.37$ & $109.867^{b} \pm 1.59$ & $1.400^{\mathrm{ab}} \pm 0.46$ & $1.067^{\mathrm{a}} \pm 0.37$ & $19.733^{\mathrm{b}} \pm 0.29$ & $98.275^{\mathrm{ab}} \pm 0.10$ & $32.863^{\mathrm{a}} \pm 3.26$ \\
\hline Seredo & $58.333^{\mathrm{b}} \pm 3.33$ & $68.600^{\mathrm{a}} \pm 1.21$ & $75.867^{\mathrm{a}} \pm 0.58$ & $116.753^{\mathrm{a}} \pm 1.89$ & $1.267^{\mathrm{ab}} \pm 0.07$ & $1.000^{\mathrm{a}} \pm 0.12$ & $20.980^{\mathrm{ab}} \pm 0.59$ & $98.485^{\mathrm{a}} \pm 0.11$ & $30.317^{\mathrm{a}} \pm 0.73$ \\
\hline Kari/Mtama-1 & $71.667^{\mathrm{a}} \pm 1.67$ & $61.600^{\mathrm{bc}} \pm 0.12$ & $70.200^{\text {cd }} \pm 0.92$ & $99.400^{\text {cde }} \pm 1.31$ & $0.600^{\mathrm{b}} \pm 0.00$ & $0.467^{\mathrm{a}} \pm 0.07$ & $21.273^{\mathrm{ab}} \pm 0.25$ & $97.914^{\mathrm{bc}} \pm 0.16$ & $37.910^{\mathrm{a}} \pm 2.29$ \\
\hline $\begin{array}{c}\text { Gadam x } \\
\text { Kari/Mtama-1 }\end{array}$ & $68.333^{\mathrm{ab}} \pm 1.67$ & $43.800^{\mathrm{f}} \pm 1.33$ & $52.200^{\mathrm{g}} \pm 0.53$ & $93.600^{\mathrm{e}} \pm 1.03$ & $1.667^{\mathrm{ab}} \pm 0.24$ & $1.267^{\mathrm{a}} \pm 0.18$ & $22.553^{\mathrm{ab}} \pm 0.63$ & $98.177^{\mathrm{ab}} \pm 0.10$ & $40.013^{\mathrm{a}} \pm 1.68$ \\
\hline Gadam x Serena & $65.000^{\mathrm{ab}} \pm 2.89$ & $53.800^{\mathrm{e}} \pm 0.40$ & $63.200^{f} \pm 0.42$ & $87.000^{f} \pm 0.99$ & $2.467^{\mathrm{a}} \pm 0.70$ & $1.800^{\mathrm{a}} \pm 0.35$ & $21.260^{\mathrm{ab}} \pm 0.17$ & $97.195^{\mathrm{de}} \pm 0.11$ & $38.867^{a} \pm 6.13$ \\
\hline $\begin{array}{c}\text { Gadam x } \\
\text { Seredo }\end{array}$ & $61.667^{\mathrm{ab}} \pm 1.67$ & $56.333^{\mathrm{de}} \pm 0.13$ & $66.967^{\mathrm{e}} \pm 0.42$ & $96.200^{\mathrm{e}} \pm 1.11$ & $2.067^{\mathrm{ab}} \pm 0.13$ & $1.667^{\mathrm{a}} \pm 0.41$ & $21.433^{\mathrm{ab}} \pm 0.82$ & $96.789^{\mathrm{e}} \pm 0.10$ & $38.013^{\mathrm{a}} \pm 3.57$ \\
\hline $\begin{array}{l}\text { Kari/ Mtama-1 } \\
\text { x Gadam }\end{array}$ & $70.000^{\mathrm{ab}} \pm 2.89$ & $58.133^{\text {cd }} \pm 0.37$ & $67.933^{\mathrm{de}} \pm 0.07$ & $97.933^{\mathrm{de}} \pm 0.48$ & $1.200^{\mathrm{ab}} \pm 0.12$ & $0.933^{\mathrm{a}} \pm 0.06$ & $23.727^{a} \pm 0.75$ & $96.175^{\mathrm{f}} \pm 0.11$ & $40.313^{\mathrm{a}} \pm 1.29$ \\
\hline Serena x Gadam & $61.667^{\mathrm{ab}} \pm 1.67$ & $63.733^{b} \pm 0.33$ & $71.400^{\mathrm{bc}} \pm 0.23$ & $103.267^{\mathrm{cd}} \pm 1.16$ & $1.933^{\mathrm{ab}} \pm 0.58$ & $1.667^{\mathrm{a}} \pm 0.13$ & $20.667^{\mathrm{b}} \pm 0.64$ & $98.399^{\mathrm{a}} \pm 0.08$ & $35.680^{\mathrm{a}} \pm 1.29$ \\
\hline $\begin{array}{c}\text { Seredo x } \\
\text { Gadam }\end{array}$ & $60.000^{\mathrm{ab}} \pm 2.89$ & $64.000^{\mathrm{b}} \pm 1.25$ & $73.400^{\mathrm{ab}} \pm 1.10$ & $104.667^{\mathrm{bc}} \pm 1.62$ & $2.067^{\mathrm{ab}} \pm 0.41$ & $1.600^{\mathrm{a}} \pm 0.58$ & $21.713^{\mathrm{ab}} \pm 0.65$ & $97.569^{\mathrm{cd}} \pm 0.06$ & $33.910^{\mathrm{a}} \pm 2.61$ \\
\hline P-Value & $0.006^{* *}$ & $<0.001^{* * *}$ & $<0.001^{* * *}$ & $<0.001^{* * *}$ & $0.077^{\mathrm{NS}}$ & $0.087^{\mathrm{NS}}$ & $0.009^{* *}$ & $0.157^{\mathrm{NS}}$ & $0.384^{\mathrm{NS}}$ \\
\hline
\end{tabular}

Means with the same letter within the column are not significantly different. ${ }^{* *},{ }^{* * *}$ significant at $1 \%$ and $0.1 \%$ respectively; NS: not significant.S.E: standard error; RG: rate of germination; DTH: days to heading; DTF: days to flowering; DTM: days to maturity; NTPP: number of tillers per plant; NRT: number of reproductive tillers; PL: panicle length; GF: grain filling; W1000S: weight of a thousand seeds; \%: percentage

Table 3 Analysis of variance showing means of the qualitative variable

\begin{tabular}{|c|c|c|c|}
\hline \multirow{3}{*}{ Treatments } & \multicolumn{3}{|c|}{ Panicle compactness } \\
\hline & Compact & Semi-loose & Loose \\
\hline & (Means \pm S.E) & $($ Mean \pm S.E) & $($ Mean \pm S.E) \\
\hline Gadam & $2.773^{\mathrm{a}} \pm 0.00$ & $0.000^{\mathrm{d}} \pm 0.00$ & $0.000^{\mathrm{d}} \pm 0.00$ \\
\hline Serena & $2.773^{\mathrm{a}} \pm 0.00$ & $0.000^{\mathrm{d}} \pm 0.00$ & $0.000^{\mathrm{d}} \pm 0.00$ \\
\hline Seredo & $0.000^{\mathrm{d}} \pm 0.00$ & $2.773^{\mathrm{a}} \pm 0.00$ & $0.000^{\mathrm{d}} \pm 0.00$ \\
\hline Kari/Mtama-1 & $0.000^{\mathrm{d}} \pm 0.00$ & $0.000^{\mathrm{d}} \pm 0.00$ & $2.773^{\mathrm{a}} \pm 0.00$ \\
\hline Gadam x Serena & $2.773^{\mathrm{a}} \pm 0.00$ & $0.000^{\mathrm{d}} \pm 0.00$ & $0.000^{\mathrm{d}} \pm 0.00$ \\
\hline Gadam x Seredo & $1.843^{\mathrm{c}} \pm 0.33$ & $2.366^{\mathrm{b}} \pm 0.33$ & $0.000^{\mathrm{d}} \pm 0.00$ \\
\hline Gadam x Kari/Mtama-1 & $1.782^{\mathrm{c}} \pm 0.58$ & $0.000^{\mathrm{d}} \pm 0.00$ & $2.395^{\mathrm{b}} \pm 0.58$ \\
\hline Serena x Gadam & $2.773^{\mathrm{a}} \pm 0.00$ & $0.000^{\mathrm{d}} \pm 0.00$ & $0.000^{\mathrm{d}} \pm 0.00$ \\
\hline Seredo X Gadam & $2.366^{\mathrm{b}} \pm 0.33$ & $1.843^{\mathrm{c}} \pm 0.33$ & $0.000^{\mathrm{d}} \pm 0.00$ \\
\hline Kari/Mtama-1 x Gadam & $2.483^{\mathrm{b}} \pm 0.58$ & $0.000^{\mathrm{d}} \pm 0.00$ & $1.596^{\mathrm{c}} \pm 0.58$ \\
\hline P-Value & $<0.001^{* * *}$ & $<0.001^{* * *}$ & $<0.001^{* * *}$ \\
\hline
\end{tabular}

Means with the same letter within the column are not significantly different, ${ }^{* * *}$ Significant at $0.1 \%$. S.E: standard error

Journal of Experimental Biology and Agricultural Sciences

http://www.jebas.org 
Table 4 Pearson correlation between quantitative variable

\begin{tabular}{|c|c|c|c|c|c|c|c|c|c|}
\hline Variables & RG & DTH & DTF & DTM & NTPP & NRT & PL & GFP & W1000S \\
\hline DTH & -0.564 & & & & & & & & \\
\hline$P$-value & 0.089 & & & & & & & & \\
\hline \multirow{2}{*}{ DTF } & -0.556 & 0.990 & & & & & & & \\
\hline & 0.095 & 0.001 & & & & & & & \\
\hline \multirow{2}{*}{ DTM } & -0.605 & 0.814 & 0.770 & & & & & & \\
\hline & 0.064 & 0.004 & 0.009 & & & & & & \\
\hline \multirow{2}{*}{ NTPP } & -0.436 & -0.269 & -0.238 & -0.398 & & & & & \\
\hline & 0.207 & 0.453 & 0.508 & 0.254 & & & & & \\
\hline \multirow{2}{*}{ NRT } & -0.438 & -0.225 & -0.197 & -0.349 & 0.980 & & & & \\
\hline & 0.206 & 0.531 & 0.585 & 0.323 & 0.001 & & & & \\
\hline \multirow{2}{*}{ PL } & 0.399 & -0.426 & -0.416 & -0.365 & -0.066 & -0.128 & & & \\
\hline & 0.253 & 0.220 & 0.231 & 0.300 & 0.856 & 0.724 & & & \\
\hline \multirow{2}{*}{ GFP } & -0.198 & 0.206 & 0.114 & 0.464 & -0.181 & -0.111 & -0.701 & & \\
\hline & 0.583 & 0.567 & 0.753 & 0.176 & 0.616 & 0.760 & 0.024 & & \\
\hline \multirow{2}{*}{ W1000S } & 0.675 & -0.757 & -0.724 & -0.858 & 0.096 & 0.045 & 0.678 & -0.682 & \\
\hline & 0.032 & 0.011 & 0.018 & 0.001 & 0.792 & 0.902 & 0.031 & 0.030 & \\
\hline \multirow{2}{*}{$\mathrm{PH}$} & 0.135 & 0.282 & 0.258 & 0.437 & -0.793 & -0.832 & 0.386 & -0.406 & 0.014 \\
\hline & 0.709 & 0.431 & 0.471 & 0.207 & 0.006 & 0.002 & 0.270 & 0.244 & 0.969 \\
\hline
\end{tabular}

Values in bold are different from 0 with a significance level of $p=0.05$

RG: rate of germination; DTH: days to heading; DTF: days to flowering; DTM: days to maturity; NTPP: number of tillers per plant; NRT: number of reproductive tillers; PL: panicle length; GFP: grain filling percentage; W1000S: weight of a thousand seeds; PH: plant height

\subsection{Estimates of heterosis}

Heterosis was tested for each quantitative trait among the crosses (Table 5). Significant variations $(\mathrm{p}<0.019)$ were observed between better parent (BPH) and mid-parent heterosis (MPH) for plant height. The MPH ranged from $-19.89 \%$ for Gadam x Serena to $16.56 \%$ for Kari/Mtama-1 x Gadam. For the same trait, the BPH ranged from $31.27 \%$ in the cross Gadam $x$ Serena to $-6.38 \%$ in Kari/Mtama-1 $x$ Gadam. Crosses between Gadam and the three other varieties recorded lower MPH and BPH in days to heading, flowering and maturity compared to their reciprocals (Table 5). This is illustrated in MPH for days to heading whereby, Gadam x Serena, Gadam x Seredo and Gadam x Kari/Mtama-1 recorded -10.93, -9.38, and -25.34 respectively that was lower than their reciprocal crosses. The days to heading varied from $-25.34 \%$ for Gadam x Kari/Mtama- 1 to $5.52 \%$ for Serena $\mathrm{x}$ Gadam. For the same trait, BPH ranged from $-28.90 \%$ to $2.05 \%$ for the $\mathrm{F}_{1}$ hybrids respectively. The MPH for days to flowering varied from $-22.93 \%$ in Gadam x Kari/Mtama-1 to $4.01 \%$ in Seredo $x$ Gadam. The BPH varied from $-25.64 \%$ for Gadam x Kari/Mtama-1 to $-3.23 \%$ for Kari/Mtama-1 $\times$ Gadam for the same trait. The crosses Gadam x Serena, Gadam x Seredo and Gadam x Kari/Mtama-1 recorded negative MPH values of $-9.59,-5.10$, and $-22.93 \%$ respectively for days to flowering compared to positive values in their reciprocal crosses (Table 5). All the $\mathrm{F}_{1}$ hybrids exhibited a negative MPH and BPH for days to maturity. For the same trait, the MPH ranged from $-16.16 \%$ for Gadam $x$ Serena to $-0.48 \%$ for Serena $x$ Gadam while BPH ranged from $-20.81 \%$ for Gadam $x$ Serena to $1.48 \%$ for Kari/Mtama-1 $\mathrm{x}$ Gadam. All the $\mathrm{F}_{1}$ hybrids exhibited positive values both for MPH and BPH for panicle length. The MPH ranged from $3.51 \%$ for Serena x Gadam to $14.42 \%$ for Kari/Mtama-1 x
Gadam while BPH ranged from $2.16 \%$ for Gadam $x$ Seredo to $11.54 \%$ for Kari/Mtama-1 x Gadam. The use of Gadam as the female parent other than Gadam x Serena resulted in a smaller panicle length than in the reciprocal crosses. Positive MPH was also observed for all the $F_{1} s$ in the number of reproductive tillers, the number of tillers per plant, panicle length, and a thousand seed weight. However, the heterosis was not significant. The lowest MPH values of $3.67 \%$ for the number of reproductive tillers and $12.52 \%$ for the number of tillers per plant were recorded in Kari/Mtama-1 x Gadam. The cross Gadam x Serena recorded the highest MPH of $50.00 \%$ for the number of reproductive tillers and MPH of $68.22 \%$ for the number of tillers per plant. The BPH ranged from $-21.72 \%$ for Kari/Mtama- 1 x Gadam to $60.93 \%$ for Gadam x Serena and $-30.01 \%$ for Kari/Mtama-1 x Gadam to $35.03 \%$ for Gadam x Serena for the number of tillers per plant and number of reproductive tillers respectively.

Grain filling differed among crosses and their reciprocals (Table 5). Significant variations $(\mathrm{p}<0.013)$ were observed in both the BPH and MPH. The MPH ranged from $-2.08 \%$ for Kari/Mtama-1 x Gadam to $0.002 \%$ for Serena x Gadam. For this trait, in both MPH and BPH, the use of Gadam as female parent reduced grain filling rate than in reciprocal crosses apart from Gadam x Kari/Mtama-1 where higher values were recorded in the reciprocal cross. The BPH of the same trait in the same crosses ranged from $-2.38 \%$ to $-0.12 \%$ (Table 5). For the weight of a thousand seeds, the MPH ranged from $4.52 \%$ for Seredo x Gadam to $17.16 \%$ for Gadam x Seredo while BPH ranged from $-1.92 \%$ for Seredo x Gadam to $12.42 \%$ for Gadam x Serena. However, for the same trait, the use of Gadam as a female parent resulted in superior MPH and BPH compared to its reciprocal crosses apart from Gadam x Kari/Mtama-1. 
Table 5 Mid parent (MPH) and better parent heterosis (BPH) in percentagefor growth and yield variables

\begin{tabular}{|c|c|c|c|c|c|c|c|c|c|c|c|c|c|c|c|c|c|c|c|c|}
\hline \multirow[t]{3}{*}{ Crosses } & \multicolumn{2}{|c|}{ PH } & \multicolumn{2}{|c|}{ RG } & \multicolumn{2}{|c|}{ DTH } & \multicolumn{2}{|c|}{ DTF } & \multicolumn{4}{|c|}{ DTM } & \multicolumn{2}{|c|}{ NTPP } & \multicolumn{2}{|c|}{ NRT } & \multicolumn{2}{|c|}{ GFP } & \multicolumn{2}{|c|}{ W1000S } \\
\hline & & & & & & & & & Perc & $t$ of hete & sis over & & & & & & & & & \\
\hline & MPH & BPH & MPH & BPH & MPH & BPH & MPH & BPH & MPH & BPH & MPH & BPH & MPH & BPH & MPH & BPH & MPH & BPH & MPH & BPH \\
\hline $\begin{array}{c}\text { Gadam x } \\
\text { Serena }\end{array}$ & -19.89 & -31.27 & 0 & -4.65 & -10.93 & -17.32 & -9.59 & -15.21 & -16.16 & -20.81 & 6.48 & 5.25 & 68.22 & 60.93 & 50.00 & 35.03 & -1.22 & -1.34 & 15.27 & 12.42 \\
\hline $\begin{array}{c}\text { Gadam x } \\
\text { Seredo }\end{array}$ & -0.02 & -15.81 & -3.90 & -11.90 & -9.38 & -17.88 & -5.10 & -11.73 & -10.27 & -17.60 & 4.09 & 2.16 & 47.64 & 34.83 & 42.91 & 25.06 & -1.74 & -1.76 & 17.16 & 9.95 \\
\hline $\begin{array}{c}\text { Gadam x } \\
\text { Kari/Mtama-1 }\end{array}$ & 4.00 & -16.47 & -3.53 & -4.65 & -25.34 & -28.90 & -22.93 & -25.64 & -5.01 & -5.84 & 8.76 & 6.02 & 56.31 & 8.74 & 40.78 & -4.95 & -0.04 & -0.35 & 10.41 & 5.55 \\
\hline $\begin{array}{c}\text { Kari/Mtama-1 } \\
\text { x Gadam }\end{array}$ & 16.56 & -6.38 & -1.18 & -2.33 & -0.91 & -5.63 & 0.29 & -3.23 & -0.61 & -1.48 & 14.42 & 11.54 & 12.52 & -21.72 & 3.67 & -30.01 & -2.08 & -2.38 & 11.23 & 6.34 \\
\hline $\begin{array}{c}\text { Serena x } \\
\text { Gadam }\end{array}$ & -2.86 & -16.77 & -5.13 & -11.90 & 5.52 & -2.05 & 2.15 & -4.20 & -0.48 & -6.01 & 3.51 & 2.31 & 31.81 & 26.09 & 38.92 & 25.06 & 0.002 & -0.12 & 5.82 & 3.20 \\
\hline $\begin{array}{c}\text { Seredo x } \\
\text { Gadam }\end{array}$ & 6.97 & -9.93 & -6.49 & -14.29 & 2.95 & -6.71 & 4.01 & -3.25 & -2.37 & -10.35 & 5.45 & 3.49 & 47.64 & 34.83 & 37.16 & 20.03 & -0.95 & -0.96 & 4.52 & -1.92 \\
\hline Mean & 0.79 & -16.10 & -3.37 & -8.29 & -6.35 & -13.08 & -5.20 & -10.54 & -5.82 & -10.35 & 7.12 & 5.13 & 44.02 & 23.95 & 35.57 & 11.70 & -1.91 & -2.34 & 10.74 & 5.92 \\
\hline $\begin{array}{l}\text { Standard } \\
\text { deviation }\end{array}$ & 12.16 & 8.53 & 2.42 & 4.98 & 11.38 & 10.09 & 10.03 & 8.92 & 6.24 & 7.48 & 4.04 & 3.50 & 19.52 & 28.02 & 16.25 & 24.44 & 1.39 & 1.63 & 5.00 & 5.05 \\
\hline
\end{tabular}

PH: plant height; RG: rate of germination; DTH: days to heading; DTF: days to flowering; DTM: days to maturity; PL: panicle length; NTPP: number of tillers per plant; NRT: number of reproductive tillers; GFP: grain filling percentage; W1000S: weight of a thousand seeds; Values in bold are significant at level alpha $=0.05$

Table 6 Analysis of variance showing tannin content $(\mathrm{mg} / \mathrm{g})$ of sorghum $\mathrm{F}_{1}$ hybrids and their parents

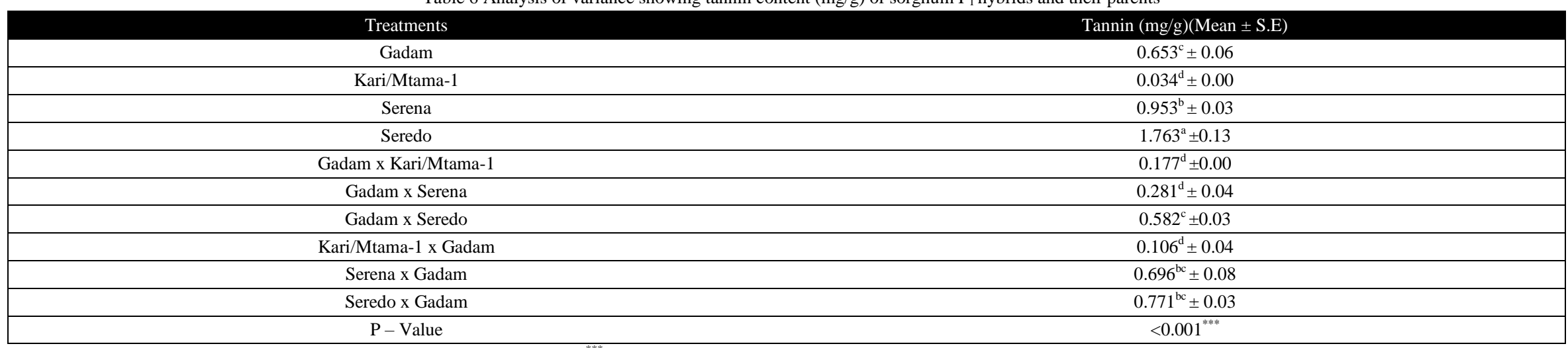

Means with the same letter within the column are not significantly different, ${ }^{* * *}$ significant at $0.1 \%$. S.E: standard error; $\mathrm{mg} / \mathrm{m}$ : milligram per gram

Journal of Experimental Biology and Agricultural Sciences

http://www.jebas.org 


\subsection{Tannin content}

There was some significant variation of tannin content among the crosses, reciprocal, and their parents at $\mathrm{p}<0.001$ (Table 6). The detectable tannin content ranged from $0.034 \mathrm{mg} / \mathrm{g}$ to $1.76 \mathrm{mg} / \mathrm{g}$. Gadam x Serena recorded a tannin content of $0.28 \mathrm{mg} / \mathrm{g}$ which differed significantly from its reciprocal (Serena $x$ Gadam) that recorded tannin content of $0.69 \mathrm{mg} / \mathrm{g}$. All other crosses did not differ significantly with their reciprocals. Crosses Gadam $x$ Kari/Mtama-1, Gadam x Serena and Kari/Mtama-1 x Gadam had significantly lower tannin content than Gadam parent. The $F_{1}$ hybrids Seredo x Gadam and Serena x Gadam recorded the highest tannin content value of $0.77 \mathrm{mg} / \mathrm{g}$ and $0.69 \mathrm{mg} / \mathrm{g}$ respectively. These crosses differed significantly from all the parents apart from Gadam that recorded a tannin content of $0.65 \mathrm{mg} / \mathrm{g}$ (Table 6).

\section{Discussion}

There was a significant difference displayed among the $\mathrm{F}_{1} \mathrm{~S}$ in height at $\mathrm{p}<0.05$ at weeks 1 to 6 (Table 1). This indicates different growth rates during the vegetative stages of plant growth. Sorghum plant is characterized by three growth stages (GS) namely, GS I or vegetative, GS II or reproductive structure formation, and GS III or grain filling stage (Maw et al., 2019). Among the parents, Serena and Kari/Mtama-1 had significantly faster vegetative growth than Gadam sorghum. In weeks $4-6$, the cross Gadam x Serena had a significantly lower vegetative growth rate than all other crosses apart from its reciprocal. The vegetative growth stage in sorghum plants is under genetic control and it is sensitive to daylight length (Takamizo et al., 2012) thus, it can be inherited. The $F_{1}$ hybrids Kari/Mtama- $1 x$ Gadam, Gadam x Kari/Mtama-1, Seredo x Gadam and Gadam x Seredo had larger panicle lengths compared to their parental genotypes. This suggests heterosis for this trait. Sorghum has significant and positive heterosis for panicle length (Jadhav \& Deshmukh, 2017). This supports the observation that there is remarkable heterosis in panicle length in sorghum hybrids in this study.

The $\mathrm{F}_{1}$ hybrids differed significantly $(\mathrm{p}<0.001)$ in days to maturity, days to flowering, and days to heading (Table 2). The maturity in sorghum is under facultative gene control at the loci $\mathrm{Ma}_{1}$ to $\mathrm{Ma}_{4}, \mathrm{Ma}_{5}$, and $\mathrm{Ma}_{6}$ (Casto et al., 2019). The time of floral initiation is mainly controlled by the gene loci $\mathrm{Ma}_{1}$ and $\mathrm{Ma}_{4}$ (Murphy et al., 2011). Depending on genotype, differences in floral initiation have been observed over time (McKinley et al., 2016). The cross between Gadam x Kari/Mtama-1 recorded significantly lower values for days to heading and days to flowering compared to the parental genotype Gadam and Kari/Mtama-1 (Table 2). This shows that crossing influenced earliness in heading and flowering time. Mohammed et al. (2015), while working on the genetic study of morphological and agronomic traits in sorghum, observed earliness for anthesis in sorghum hybrids compared to their parents. Early flowering was recorded in the cross Gadam x Kari/Mtama-1 with a mean of 52.2 days, however, it had 93.60 days to maturity which was significantly higher compared to the cross Gadam x Serena that scored 87.000 days. The observed difference can be attributed to differences in sensitivity in the flowering phase for the cross Gadam x Kari/Mtama-1 compared to other crosses like Gadam x Serena. This is in harmony with the observation by Murphy et al. (2011) who reported that flowering time is both under environmental and genetic control. Among the $F_{1}$ hybrids, Serena $x$ Gadam recorded the highest values for grain filling percentage. This is an exhibition of the superiority of the cross compared to the other crosses.

The crosses Gadam x Seredo, Gadam x Kari/Mtama-1, and their reciprocals exhibited high variability in panicle compactness compared to their parents. This suggested that both non-additive and additive gene action control this trait. Similar results have been reported by Mohammed et al. $(2015,2018)$ in sorghum. The results in crosses where Gadam was the male parent gave a more domineering influence, especially in plant height, days to heading, the grain filling percentage, days to flowering, length of the panicle, and days to maturity (Table 2). This is evidence that besides the direct genetic effects, the maternal effects were also involved in the inheritance of these characters. Cytoplasmic effects in crossing have been reported to significantly influence the inheritance of both morphological and agronomic traits in grain sorghum (Mohammed et al., 2015), such as days to flowering and plant height. These observations indicate that the cytoplasmic factors influenced the inheritance of such traits.

Degrees of correlation among the quantitative characters studied are the key in the selection of useful traits towards improving the productivity of sorghum. For example, a positive and significant correlation was observed between the days to heading and days to maturity and days to flowering indicating that earliness in anthesis and maturity in sorghum can be attained through selection for fewer days to heading. A similar positive correlation has been reported by Rutayisire et al. (2020) in sorghum. The number of tillers per plant had a significant positive correlation with the number of reproductive tillers (Table 4). This indicates that the number of reproductive tillers in sorghum can be increased through selection for more tillers per plant. Also, a positive correlation between the weight of a thousand seeds and the panicle length indicates that greater a thousand seed weight in sorghum can be attained through selection for sorghum lines with higher panicle length. These traits are considered as the main characters towards improving the sorghum grain yield (Ali et al., 2011; Reddy et al., 2013). A useful positive correlation has also been reported in rice (Ratna et al., 2015). 
A significant negative correlation observed between the grain filling percentage and panicle length together with the weight of a thousand seeds among hybrids suggests that grain filling percentage is higher in sorghum lines with small panicle length and that, the more the number of grains per panicle, the lower the grain weight. Low grain filling has been observed in crops such as rice due to $F_{1}$ sterility that is caused by parental incompatibility (Mizuta et al., 2010). In rice, it has been reduced by the inclusion of $S^{5 n}$ gene for wide compatibility (Ouyang et al., 2010). The inclusion of a similar gene in sorghum could lead to a more positive correlation. There exists an inherent trade-off between seed number and seed weight where the fewer the number of seeds the more the weight and vice versa. Yang et al. (2010) reported that fewer seeds per panicle resulted in the crop getting maximum photosynthetic products necessary for seed development leading to improved seed weight.

The negative correlation between plant height with the number of tillers per plant and reproductive tillers indicates that increased branching in sorghum is associated with dwarfism. Liao et al. (2019) reported a negative correlation between plant height and tiller number. However, the association between tillering with other leaf and plant size traits has not been fully elucidated. Amare et al. (2015) while working on variability for yield, yield-related attributes, and relationship among sorghum traits, reported that plant height correlated negatively with days to heading and days to flowering although the correlations were not significant. Increased number of tillers especially in rice has been reported to lead to decreased height, although, the association is not strong, as the total number of tillers and final plant height is coordinated by both hormones, genetic and environmental factors (Liao et al., 2019).

Different variations for BPH and MPH were recorded for the traits under study among the $\mathrm{F}_{1}$ hybrids. In the current study, the crosses Gadam x Serena, Gadam x Seredo and reciprocal cross Serena $x$ Gadam exhibited negative MPH and BPH for plant height which resulted in shorter hybrids. The shortness in plant height among $F_{1}$ hybrids suggests that there could be dominance or additive gene effects for dwarfness. Higgins et al. (2014) while working on sorghum reported that, tallness is a partially dominant trait and that four recessive, non-linked brachytic dwarfing genes control plant height. This is aligned with the works of Shukla et al. (2017) who reported sorghum hybrids with shorter height than their parental genotypes. Negative BPH in days to heading, maturity, and flowering recorded in $\mathrm{F}_{1}$ hybrids is an indication of early anthesis and maturity in sorghum hybrids compared to their parental genotypes. Days to maturity and flowering have been reported to have negative heterosis in sorghum (Mindaye et al., 2016; Chikuta et al., 2017; Crozier et al., 2020). Positive MPH recorded for the number of reproductive tillers, the weight of a thousand seeds, panicle length, and the number of tillers per plant across all $F_{1}$ hybrids is an indication of possible yield improvement of Gadam sorghum through hybridization. Sorghum yield improvement using hybrid has been reported in China and India (Ashok et al., 2019).

In this research, the difference between the performance of crosses and their reciprocal was observed. For example, in 1000 grain weight, the use of Gadam as a female parent gave a better hybrid in all the crosses apart from Gadam x Kari/Mtama-1. Grain filling was better where Gadam was the male parent apart from Kari/Mtama-1 x Gadam where its reciprocal performed better indicating paternal gene influence. Therefore, in sorghum hybrid seed production, the choice of the maternal or paternal parent is significant.

Significance variations observed in tannin content among the parents and the $F_{1}$ hybrids can be attributed to the genotype. In the current study, the tannin content was detected at $1.76 \mathrm{mg} / \mathrm{g}$, $0.95 \mathrm{mg} / \mathrm{g}, 0.65 \mathrm{mg} / \mathrm{g}$, and $0.03 \mathrm{mg} / \mathrm{g}$ in the parental genotypes of Seredo, Serena Gadam, and Kari/Mtama-1 respectively. This differed from the findings of Omondi et al. (2012) those who reported fewer tannin levels of $0.81 \%$ C.E, $0.03 \%$ C.E, $2.22 \%$ C.E, and $1.2 \%$ C.E in Gadam, Kari/Mtama-1, Seredo, and Serena respectively. The variations observed between the results could be due to differences in the method used in the analysis. However, the tannin content range of $0.106 \mathrm{mg} / \mathrm{g}$ to $0.77 \mathrm{mg} / \mathrm{g}$ observed among the $F_{1}$ hybrids is within the findings by Mabelebele et al. (2015), who reported a sorghum tannin content range of $0.1 \mathrm{~g} / \mathrm{g}$ to $3.2 \mathrm{~g} / \mathrm{g}$.

\section{Conclusion}

In some traits, better performance was observed in hybrids compared to their parents. This was illustrated in cross Gadam $\mathrm{x}$ Serena that had a short stature compared to its parents. Both the mid parent and better parent heterosis were observed among $F_{1}$ hybrids, however, they did not differ significantly in most quantitative traits assessed except for the plant height and grain filling percentage. All the $\mathrm{F}_{1}$ hybrids have desirable negative $\mathrm{BPH}$ heterosis for plant height. Incompatibility in terms of grain filling percentage was seen more in the cross Kari/Mtama-1 x Gadam. In this trait, the male parent tended to have more influence. This was demonstrated by significantly lower grain filling percentage recorded in $\mathrm{F}_{1}$ hybrids where Gadam was the maternal parent than the reciprocals. The maternal influence was noted in several traits such as days to heading, flowering and maturity, and a thousandgrain weight among sorghum $F_{1}$ hybrids. The performance of hybrids differed significantly from their reciprocals. Days to heading, flowering, and maturity correlate positively. Tannin is not significantly influenced by hybridization. This was demonstrated by the absence of significant difference among the $F_{1}$ hybrids from the parental Gadam apart from the cross Gadam x Serena. 


\section{Acknowledgment}

The experimental site was issued by the University of Embu.

The meteorological data were obtained from the Trans-African Hydro-Meteorological Observatory (TAHMO).

\section{Conflict of interest}

No possible conflict of interest has been declared concerning the publishing of this paper.

\section{References}

Abraha MT, Shimelis HA, Laing MD, Assefa K (2017) Selection of drought-tolerant tef (Eragrostis tef) genotypes using drought tolerance indices. South African Journal of Plant and Soil 34(4): 291-300. https://doi.org/10.1080/02571862.2017.1300696.

Adams CB, Erickson JE, Campbell DN, Singh MP, Rebolledo JP (2015) Effects of row spacing and population density on yield of sweet sorghum: Applications for harvesting asbillets. Agronomy Journal 107(5): 1831-1836. https://doi.org/10.2134/agronj14.0295.

Akosambo-Ayoo LM, Bader M, Loerz H, Becker D (2011) Transgenic sorghum (Sorghum bicolor L. Moench) developed by transformation with chitinase and chitosanase genes from Trichoderma harzianum expresses tolerance to anthracnose. African Journal of Biotechnology10(19): 3659 - 3670. https://doi.org/10.5897/AJB10.1530.

Ali MA, Abbas A, Awan SI, Jabran K, Gardezi SDA (2011) Correlated response of variousmorpho-physiological characters with grain yield in sorghum landraces at different growth phases. Journal of Animal and Plant Science 21(4): 671-679. http://thejaps.org.pk/docs/21-4/30.pdf.

Amare K, Zeleke H, Bultosa G (2015) Variability for yield, yieldrelated traits and association among traits of sorghum (Sorghum bicolor (L.) Moench) varieties in Wollo, Ethiopia. Journal of Plant Breeding and Crop Science7(5): 125-133. https://doi.org/10.5897/ JPBCS2014.0469.

Amelework BA, Shimelis HA, Tongoona P, Mengistu F, Laing MD, Ayele DG (2016) Sorghum production systems and constraints, and coping strategies under drought-prone agroecologies of Ethiopia. South African Journal of Plant and Soil 33(3):207-217. https://doi.org/10.1080/02571862.2016.1143043.

Aruna C, Cheruku D (2019) Genetic Improvement of Grain Sorghum. In: Aruna C, Visarada KBRS, Bhat BV, Tonapi VA (Eds) Breeding sorghum for diverse end uses. Woodhead Publishing, Cambridge, UK 157-173. https://doi.org/10.1016/ B978-0-08-101879-8.00010-3.
Aruna C, Visarada K (2019) Sorghum Grain in Food and Brewing Industry. In Breeding Sorghum for Diverse End Uses, Elsevier publication Pp. 209-228. https://doi.org/10.1016/B978-0-08101879-8.00013-9.

Ashok Kumar A, Ciampitti I, Prasad V (2019) Sorghum Hybrids Development for Important Traits: Progress and Way Forward. Agronomy Monographs 58: 97-117. https://doi.org/10.2134/ agronmonogr58.2014.0059.

Bean BW, Baumhardt RL, McCollum FT, McCuistion KC (2013) Comparison of sorghum classes for grain and forage yield and forage nutritive value. Field Crops Research 142:20-26. https://doi.org/10.1016/j.fcr.2012.11.014.

Burrow G, Burke JJ, Xin Z, Franks CD (2011) Genetic dissection of early-season cold tolerance in sorghum (Sorghum bicolor (L.) Moench). Molecular Breeding 28(3): 391-402. https://doi.org/ 10.1007/s11032-010-9491-4.

Bonin CL, Heaton EA, Cogdill TJ, Moore KJ (2016) Management of sweet sorghum for biomass production. Sugar Tech18(2): 150159. https://doi.org/10.1007/s12355-015-0377-y.

Calone R, Sanoubar R, Lambertini C, Speranza M, Vittori AL, Vianello G, Barbanti L (2020) Salt tolerance and Na allocation in Sorghum bicolor under variable soil and water salinity. Plants 9(5): 561. https://doi.org/10.3390/plants 9050561 .

Casto AL, Mattison AJ, Olson SN, Thakran M, Rooney WL, Mullet JE (2019) Maturity2, a novel regulator of flowering time in Sorghum bicolor, increases expression of SbPRR37 and SbCO in long days delaying flowering. Plos One 14(4): e0212154. https://doi.org/10.1371/journal.pone.0212154.

Che P, Zhao ZY, Glassman K, Dolde D, Hu TX, Jones TJ, Gruis DF, Obukosia S, Wambugu F, Albertsen MC (2016) Elevated vitamin $\mathrm{E}$ content improves all-trans $\beta$-carotene accumulation and stability in biofortified sorghum. Proceedings of the National Academy of Sciences113(39):11040-11045. https://doi.org/ 10.1073/pnas.1605689113.

Chen J, Cao F, Shan S, Yin X, Huang M, Zou Y (2019) Grain filling of early season rice cultivars grown under mechanical transplanting. Plos One 14(11): e0224935. https://doi.org/10.1371/ journal.pone.0224935.

Chikuta S, Odong TL, Kabi F, Rubaihayo P, BomBom A, Okori P, Gibson P, Rubaihayo P, Kiryowa M, Ddamulira G (2017) Combining ability and heterosis of selected grain andforage dualpurpose sorghum genotypes. Journal of Agricultural Science 9(2): 122-130. https://doi.org/10.5539/ jas.v9n2p122. 
Crozier D, Jr LH, Klein PE, Klein RR, Rooney L, Crozier D (2020) Predicting heterosis in grain sorghum hybrids using sequence-based genetic similarity estimates. Journal of Crop Improvement 34(5): 600-617. https://doi.org/10.1080/ 15427528.2020 .1748152 .

De Mendibru FA (2019) Statistical procedures for agricultural research. $\mathrm{R}$ package version 4.0-3. Available at: https://cran.rproject.org/package=agricolae, accessed on 01 April 2019.

De Mey Y, Demont M, Diagne M (2012) Estimating Bird Damage to Rice in Africa: Evidence from the Senegal River Valley. Journal of Agricultural Economics63(1):175-200. https://doi.org/10.1111/ j.1477-9552.2011.00323.x.

Dykes L (2019) Tannin analysis in sorghum grains. Sorghum Methods and Protocols1931:109-120. https://doi.org/10.1007/9781-4939-9039-9_8.

Esipisu I (2011) Gadam sorghum in semi-arid Eastern Kenya. In Sorghum Proving Popular with Kenyan Farmers. Available at Http://ipsnews.net/news.asp?idnews=55737. Accessed January 2016.

FAOSTAT (2019) Food and agriculture data, 2019. Available at https://www.fao.org/faostat/, accessed on 10 April 2019.

FAOSTAT, FAO (2017) Food and agriculture data. Food and Agriculture Organization: Roma, Italy. http://www.fao.org/ faostat/en/\#data/QC.

Grossenbacher DL, Brandvain Y, Auld JR, Burd M, Cheptou PO, Conner JK, Grant AG, HovickSM, Pannell JR, Pauw A, Petanidou T, Randle AM, Rubio de Casas R, Vamosi J, Winn A, Igic B, Busch JW, Kalisz S, Goldberg EE (2017) Self-compatibility is over-represented on islands. New Phytologist215(1), 469-478. https://doi.org/10.1111/nph.14534.

Hadebe ST, Modi AT, Mabhaudhi T (2017) Drought Tolerance and Water Use of Cereal Crops: A Focus on Sorghum as a Food Security Crop in Sub-Saharan Africa. Journal of Agronomy and Crop Science 203(3): 177-191. https://doi.org/10.1111/jac.12191.

Hanway JJ, Olson RA (2012) Phosphate nutrition of corn, sorghum, soybeans, and small grains. In The role of phosphorus in agriculture. Wiley Online Library Pp. 681-692. https://doi.org/10.2134/1980.roleofphosphorus.c25.

Hettyey A, Hegyi G, Puurtinen M, Hoi H, Torok J, Penn DJ (2010) Mate choice for genetic benefits: time to put the pieces together. Ethology 116(1): 1-9. https://doi.org/10.1111/j.14390310.2009.01704.x.
Higgins RH, Thurber CS, Assaranurak I, Brown PJ (2014) Multiparental mapping of plant height and flowering time QTL in partially isogenic sorghum families. G3: Genes, Genome, Genetics 4(9): 1593-1602. https://doi.org/10.1534/g3.114.013318.

Jadhav RR, Deshmukh DT (2017) Heterosis and Combining Ability Studies in Sorghum (Sorghum bicolor L.Moench) Over the Environments. International Journal of Current Microbiology and Applied Sciences 6(10): 3058-3064. https://doi.org/10.20546/ ijcmas.2017.610. 360 .

Jordan DR, Mace ES, Cruickshank AW, Hunt CH, Henzell RG (2011) Exploring and exploiting genetic variation from unadapted sorghum germplasm in a breeding program. Crop Science 51(4): 1444-1457. https://doi.org/10.2135/cropsci2010.06.0326.

Kante M, Rattunde F, Nebie B, Sissoko I, Diallo B, Diallo A, Toure A, Weltzien E, Haussmann BIG, Leiser WL (2019) Sorghum hybrids for low-input farming systems in West Africa: Quantitative genetic parameters to guide hybrid breeding. Crop Science 59(6): 25442561. https:// doi.org/10.2135/cropsci2019.03.0172.

Kassambara A (2018) ggpubr: 'ggplot2'Based Publication Ready Plots. R package version 0.1.8, $\mathrm{R}$ Foundation for Statistical Computing, Vienna, Austria. Retrieved on 12 September 2020.

Kavoi J, Kisilu R, Kamau G, Wafula J, Njangungi N, Nganga T (2013) Gadam Sorghum production and marketing through a PublicPrivate Partnership in Eastern Kenya, KARI Nairobi, Kenya. January, 39. https://www.researchgate.net/publication/270516442.

Kim YJ, Silva J, Zhang D, Shi J, Joo SC, Jang MG, Kwon WS, Yang DC (2016) Development of interspecies hybrids to increase ginseng biomass and ginsenoside yield. Plant Cell Reports 35(4): 779-790. https://doi.org/10.1007/s00299-015-1920-8.

Kumar T, Dweikat I, Sato S, Ge Z, Nersesian N, Chen H, Elthon T, Bean S, Ioerger BP, Tille M (2012) Modulation of kernel storage proteins in grain sorghum (Sorghum bicolor (L.) Moench). Plant Biotechnology Journal 10(5): 533-544. https://doi.org/10.1111/ j.1467-7652.2012.00685.x

Leducq JB, Gosset CC, Poiret M, Hendoux F, Vekemans X, Billiard S (2010) An experimental study of the S-Allee effect in the self-incompatible plant Biscutella neustriaca. Conservation Genetics 11(2): 497-508. https://doi.org/10.1007/s10592-0100055-2.

Mabelebele M, Siwela M, Gous RM, Iji PA (2015) Chemical composition and nutritive value of South African sorghum varieties as feed for broiler chickens. South African Journal of Animal Science 45(2): 206-213. https://doi.org/10.4314/sajas.v45i2.12. 
Liao Z, Yu H, Duan J, Yuan K, Yu C, Meng X, Kou L, Chen M, Jing Y, Liu G (2019) SLR1 inhibits MOC1 degradation to coordinate tiller number and plant height in rice. Nature communications 10(1): 1-9. https://www.nature.com/articles/s41467-019-10667-2.

Maheswari M, Varalaxmi Y, Vijayalakshmi A, Yadav SK, Sharmila P, Venkateswarlu B, Vanaja M, Saradhi PP (2010) Metabolic engineering using mild gene enhances tolerance to water deficit and salinity in sorghum. Biologia Plantarum 54(4): $647-$ 652. https://doi.org/10.1007/s10535-010-0115-y.

Maluk MD, Ngugi K, Olubayo F, Manyasa E, Muthomi J, Nzuve F, Ochanda N (2019) Combining Ability for Earliness and Yield among South Sudanese $F_{1}$ Sorghum Genotypes. Research journali's Journal of Agriculture 6(3): 1-13. http://oar.icrisat.org/11749/1/Combining_Ability_for_Earliness_a nd_Yield_Among_South_Sudanese_F1_Sorghum_genotypes.pdf.

Massel K, Campbell BC, Mace ES, Tai S, Tao Y, Worland BG, Jordan DR, Botella JR, Godwin ID (2016) Whole-genome sequencing reveals potential new targets for improving nitrogen uptake and utilization in Sorghum bicolor. Frontiers in Plant Science 7: 1544. https://doi.org/10.3389/fpls.2016.01544.

Maw MJW, Houx JH, Fritschi FB (2019) Nitrogen content and use efficiency of sweet sorghum grown in the lower Midwest. Agronomy Journal 111(6): 2920-2928. https://doi.org/10.2134/ agronj2018.08.0489.

McKinley B, Rooney W, Wilkerson C, Mullet J (2016) Dynamics of biomass partitioning, stem gene expression, cell wall biosynthesis, and sucrose accumulation during the development of Sorghum bicolor. The Plant Journal 88(4): 662-680. https://doi.org/10.1111/tpj.13269.

Micheni AN, Karuma AN, Gicheru PT (2018) Growth, Production, Potentials and Compatibility of Maize-Bean Intercrops: Results from On-Station Trials in Embu, Kenya. Advanced Agricultural Research \& Technology Journal, II(2): 213-219. https://isasat.org/vol-ii-issue-ii-july-2018/16_AARJ_II_2_Micheni et al_213-219.pdf.

Madić M, Djurović D, Knezevic D, Paunović A (2014) Combining abilities for spike traits in a diallel cross of barley. Journal of Central and European Agriculture 15(1): 108-116. https://doi.org/10.5513/JCEA01/15.1.1419.

Mindaye TT, Mace ES, Godwin ID, Jordan DR (2016) Heterosis in locally adapted sorghum genotypes and potential of hybrids for increased productivity in contrasting environments in Ethiopia. Crop Journal 4(6): 479-489. https://doi.org/10.1016/j.cj.2016.06.020.
Mizuta Y, Harushima Y, Kurata N (2010) Rice pollen hybrid incompatibility caused by reciprocal gene loss of duplicated genes. Proceedings of the National Academy of Sciencesof the United States of America 107(47): 20417-20422. https://doi.org/10.1073/ pnas. 1003124107.

Mofokeng MA, Shargie NG (2016) Bird damage and control strategies in grain sorghumproduction. International Journal of Agricultural and Environmental Research 2(4): 264-269. https://www.researchgate.net/profile/Maletsema_Mofokeng2/publi cation/312159416.

Mohammed R, Are AK, Bhavanasi R, Munghate RS, Kavi Kishor PB, Sharma HC (2015) Quantitative genetic analysis of agronomic and morphological traits in sorghum, Sorghum bicolor. Frontiers in Plant Science 6(11): 945. https://doi.org/10.3389/fpls.2015.00945.

Mohammed R, Kumar A, Rajendra A, Gaddameedi A, Kishor K, Bilhan P, Sharma HC (2018) Pattern of genetic inheritance of morphological and agronomic traits of sorghum associated with resistance to sorghum shoot fly, Atherigona soccata. Euphytica. https://doi.org/10.1007/s10681-018-2111-9.

Munyao JK, Gathaara MH, Micheni AN (2019) Effects of conservation tillage on maize (Zea mays L.) and beans (Phaseolus vulgaris L.) chlorophyll, sugars and yields in Humic Nitisols soils of Embu County, Kenya. African Journal of Agricultural Research 14(29): 1272-1278. https://doi.org/10.5897/AJAR2019.14086.

Murphy RL, Klein RR, Morishige DT, Brady JA, Rooney WL, Miller FR, Dugas DV, Klein PE, Mullet JE (2011) Coincident light and clock regulation of pseudo response regulatorprotein 37(PRR37) controls photoperiodic flowering in sorghum. Proceedings of the National Academy of Sciences108(39): 1646916474. https://doi.org/10.1073/pnas.1106212108.

Mutisya DL, Karanja DR, Kisilu RK, Mutisya DL, Karanja DR, Economic RKK, Mutisya DL, Karanja DR, Kisilu RK (2016) Economic advantage of sorghum harvest at soft dough grain stage to prevent bird damage Economic advantage of sorghum harvest at soft dough grain stage to prevent bird damage. Cogent Food \& Agriculture 64(1): 1259141 https://doi.org/10.1080/ 23311932.2016.1259141.

Muui C, Muasya RM, Kirubi DT (2013) Baseline survey on factors affecting sorghum production and use in eastern Kenya. African Journal of Food, Agriculture, Nutrition and Development 13(01): 7339-7342. https://doi.org/10.18697/ajfand.56.11545.

Mwadalu R, Mwangi M (2013) The potential role of sorghum in enhancing food security insemi-arid eastern Kenya: A review. Journal of Applied Biosciences 71(1):5786. https://doi.org/10.4314/jab.v71i1.98826. 
Ngugi K, Maswili R (2011) Phenotypic diversity in sorghum landraces from Kenya. African Crop Science Journal 18(4): 165173. https://doi.org/10.4314/acsj.v18i4.68644.

Ochieng L, Mathenge P, Muasya R (2011) A survey of on-farm seed production practices of sorghum (Sorghum bicolor L. Moench) in Bomet District of Kenya. African Journal of Food, Agriculture, Nutrition and Development 11(5): 5232-5253. https://doi.org/10.4314/ajfand.v11i5.70448.

Ohadi S, Hodnett G, Rooney W, Bagavathiannan M (2017) Gene Flow and its Consequences in Sorghum spp. Critical Reviews in Plant Sciences 36(5-6): 367-385. https://doi.org/10.1080/ 07352689.2018 .1446813$.

Omondi EGO, Makobe MN, Onyango CA, Matasyoh LG, Imbuga MO, Kahangi EN (2012) Nutritional evaluation of mutants and somaclonal variants of sorghum. Scientific Conference Proceedings 5(12): 577-587. http://www.elearning.jkuat.ac.ke/.

Ouyang Y, Liu YG, Zhang G (2010) Hybrid sterility in plant: stories from rice. Current Opinion in Plant Biology 13(2): 186192. https://doi.org/10.1016/j.pbi.2010.01.002

Prażak R (2016) Prospects for Sorghum cultivation in Poland. Acta Agrobatanica 1-8. https://doi.org/10.5586/aa.1661.

R Development Core Team (2015) A language and environment for statistical computing. R Foundation for Statistical Computing, Vienna. Available at: https://www.r-project.org., accessed on 01 April 2019.

Ratna M, Begum S, Husna A, Dey S, Hossain M (2015) Correlation and path coefficients analyses in basmati rice. Bangladesh Journal of Agricultural Research 40: 153-161. https://doi.org/10.3329/bjar.v40i1.23768.

Rattunde HFW, Weltzien E, Diallo B, Diallo AG, Sidibe M, Toure AO, Rathore A, Das RR, Leiser WL, Toure A (2013) Yield of photoperiod-sensitive sorghum hybrids based on Guinea-race germplasmunder farmers' field conditions in Mali. Crop Science 53(6): 2454-2461. https://doi.org/10.2135/cropsci2013.03.0182.

Reddy RN, Madhusudhana R, Mohan SM, Chakravarthi DVN, Mehtre SP, Seetharama N, Patil JV (2013) Mapping QTL for grain yield and other agronomic traits in post-rainy sorghum [Sorghum bicolor (L.) Moench]. Theoretical and Applied Genetics 126(8): 1921-1939. https://doi.org/10.1007/s00122-013-2107-8.

Rutayisire A, Mukayiranga A, Habineza JC, Avosa M, Edema R, Lubadde G (2020) Effectof low- temperature stress on-field performance of highland sorghum (Sorghum bicolor (L.) Moench) at flowering stages. Journal of Plant Breeding and Crop Science 12(1): 25-33. https://doi.org/10.5897/JPBCS2019.0844.

Seo KH, Mohanan P, Yang DU, Kim YJ, Kwon WS, Yang DC (2019) Interspecies hybrids of Panax ginseng Meyer new line 0837 and Panax quinquefolius generated superior $F_{1}$ hybrids with greater biomass and ginsenoside contents. Horticulture, Environment and Biotechnology 60(4): 573-583. https://doi.org/10.1007/s13580019-00154-4.

Shukla S, Felderhoff TJ, Saballos A, Vermerris W (2017) The relationship between plantheight and sugar accumulation in the stems of sweet sorghum (Sorghum bicolor (L.) Moench). Field Crops Research203: 181-191. https://doi.org/10.1016/ j.fcr.2016.12.004.

Smale M, Assima A, Kergna A, Theriault V, Weltzien E (2018) Farm family effects of adopting improved and hybrid sorghum seed in the Sudan Savanna of West Africa. Food Policy74: 162171. https://doi.org/10.1016/j.foodpol.2018.01.001.

Suguna M, Aruna C, Deepika C, Ratnavathi CV, Tonapi VA (2021) Genetic analysis of semolina recovery and associated traitsA step towards breeding for specific end uses in sorghum (Sorghum bicolor (L.) Moench). Journal of Cereal Sciences 100(7): 103226. https://doi.org/10.1016/j.jcs.2021.103191.

Sulistyawati, Dyah R, Jabal TI, Maftuchah (2019) Genetic diversity of local sorghum (Sorghum bicolor) genotypes of East Java, Indonesia for agro-morphological and physiological traits. Biodiversitas Journal of Biological Diversity 20(9): 2503-2510. https://doi.org/10.13057/biodiv/d200910.

Takamizo T, Nakatsu S, Nagamura Y, Fujimori M, Tarumoto I (2012) Mapping of DNA markers linked to a thermosensitivity gene in sorghum. Bull NARO Institute of Livestock and Grassland Science12: 1-8.https://www.nairo.affrc.go.jp/publicity_report/ publication/archive/files/nilgs_kenhou_12_01.pdf.

Thivierge MN, Chantigny MH, Seguin P, Vanasse A (2015) Sweet pearl millet and sweet sorghum have high nitrogen uptake efficiency under cool and wet climate. Nutrient Cycling in Agroecosystems 102(2): 195-208. https://doi.org/10.1007/s10705015-9689-2.

Timu AG, Mulwa R, Okello J, Kamau M (2014) The role of varietal attributes on adoption of improved seed varieties: the case of sorghum in Kenya. Agriculture \& Food Security 3(1): 1-7. https://doi.org/10.13057/biodiv/d200910.

Visarada KBRS, Venkateswaran K (2018) Wide hybridization. In Breeding Sorghum forDiverse End UsesPp. 131-139. https://doi.org/10.1016/B978-0-08-101879-8.00008-5. 
Wang YH, Upadhyaya HD, Dweikat I (2016) Sorghum. In Genetic and Genomic Resources for Grain Cereals Improvement 1978, pp. 227-251. https://doi.org/10.1016/B978-0-12-802000-5.00005-8.

Wright SI, Kalisz S, Slotte T (2013) Evolutionary consequences of self-fertilization in plants Proceedings of Biological Science 280 20130133, 1-10. https://doi.org/10.1098/rspb.2013.0133.

Wu G, Johnson SK, Bornman JF, Bennett S, Singh V, Fang Z (2016) Effect of genotype and growth temperature on sorghum grain physical characteristics, polyphenol content, and antioxidant activity. Cereal Chemistry93(4): 419-425. https://doi.org/10.1094/ CCHEM-01-16-0003- R.

Xie P, Shi J, Tang S, Chen C, Khan A, Zhang F, Xiong Y, Li C, He W, Wang G, Lei F, Wu Y, Xie Q (2019) Control of Bird
Feeding Behaviour by Tannin1 through Modulating the Biosynthesis of Polyphenols and Fatty Acid-Derived Volatiles in Sorghum. Molecular Plant12(10): 1315-1324. https://doi.org/ 10.1016/j.molp.2019.08.004.

Yang Z, van Oosterom EJ, Jordan DR, Doherty A, Hammer GL (2010) Genetic variation in potential kernel size affects kernel growth and yield of sorghum. Crop Science 50(2): 685-695. https://doi.org/10.2135/cropsci2009.06.0294.

Young AG, Broadhurst LM, Thrall PH (2012) Non-additive effects of pollen limitation and self-incompatibility limitation and selfincompatibility reduce plant reproductive success and population viability. Annals of Botany109(3): 643-653. https://doi.org/ 10.1093/aob/mcr290. 